\title{
A brief history of HIV vaccine research: stepping back to the drawing board?
}

\author{
Frank Miedema
}

\begin{abstract}
In September 2007, it was announced that the most promising HIV vaccine trial had to be stopped because it had failed to show the protection that was hoped for. Here, the history of HIV vaccine development from the discovery of HIV-1 in 1983 until 2008, the underlying ideas on protective immunity to HIV and potential avenues for vaccine research are discussed. (c) 2008 Wolters Kluwer Health | Lippincott Williams \& Wilkins
\end{abstract}

AIDS 2008, 22:1699-1703

Keywords: HIV vaccine, protective immunity, recombinant viral vectors, T cells

The development of an efficacious vaccine against HIV is considered one of the greatest challenges to fight the AIDS epidemic. Ever since the discovery of HIV-1 in the spring of 1984, opinion leaders and administrators involved in HIV research have put down strong claims of the delivery of an AIDS vaccine in the next $5-10$ years. In September 2007, it was announced that the STEP and Phambili trials conducted with the most advanced MRKAd5 Trivalent HIV vaccine, an adenovirus 5-based vector with HIV-1 subtype B Gag, Pol, or Nef, given three times in a $1: 1: 1$ ratio were stopped. Despite promising results in the SIV macaque model [1], interim analysis of the human trial showed no protection from HIV infection and more importantly, not even a lowering of viral set point. In fact, those vaccinated who had high preexisting immunity to the Adeno- 5 viral vector showed a trend towards increased risk for becoming HIV infected (http://www.iavireport.org/Issues/Issue11-5/Step.asp).

Here, a brief critical review of the hypotheses that formed the main basis of the last decade of HIV vaccine research and development is presented.

\section{Prologue}

Neutralizing antibodies are the best, if not the only, correlate of protection for all successfully working vaccines known to date. Logically, neutralizing antibodies were the first choice for vaccine-induced immunity against HIV and much of the research in the first 10 years after 1984 focused on humoral anti-HIV immunity. This research program was questioned when in the early $1990 \mathrm{~s}$ it appeared that antibodies, and also soluble CD4 molecules, that could efficiently block T-cell line adapted HIV-1 isolates failed to neutralize primary HIV-1 isolates. It became gradually clear that the classical vaccinology approach of a subunit envelope vaccine in aluminum hydroxide (alum) that by definition mainly induced an antibody response would not suffice. At that time, these novel insights and drawbacks significantly delayed planned trials with candidate vaccines and made scientists abandon the idea of neutralizing antibody-mediated protection elicited by a vaccine. In addition, an HIV vaccine delivering sterilizing immunity to infection was believed to be non-realistic and the hope was that a vaccine could induce immunity that would protect from progression to disease [2,3]. Evidence for T-cell protection came from early vaccine studies in rhesus monkeys by Hirsch et al. [4] followed some years later by seminal studies by Shiver and colleagues $[1,5]$, in which although no sterile protection was shown, there was evidence of prolonged survival after homologous SIV challenge, and this appeared to be associated with a lower viral set point. Because cellular responses are believed to be crucial for

University Medical Center Utrecht, Utrecht, The Netherlands.

Correspondence to Frank Miedema, University Medical Center Utrecht, Lundlaan 6, 3584EA Utrecht, The Netherlands.

E-mail: f.miedema@umcutrecht.nl

Received: 14 December 2007; accepted: 25 March 2008.

DOI:10.1097/QAD.0b013e3283021a61

ISSN 0269-9370 @ 2008 Wolters Kluwer Health | Lippincott Williams \& Wilkins Copyright @ Lippincott Williams \& Wilkins. Unauthorized reproduction of this article is prohibited. 
inhibition of progression to disease the field shifted to become heavily focused on T-cell immunity.

To define 'protective' T-cell immunity, many laboratories set out to study patients at different stages of HIV infection. Important studies showed that antibodymediated depletion of CD8 T cells resulted in increased viral load in SIV-infected rhesus monkeys [6], and a temporal relationship between control of viremia and cytotoxic T lymphocyte (CTL) responses in acute HIV infection was shown [7]. From 1994 onwards, a host of data was published on HIV-specific CD8 and CD4 T-cell immunity mapping responses to viral proteins and peptides, initially using the classical approaches of T-cell lines and CTL precursor (CTLp) limiting dilution assays [8]. The original thought that T-cell immunity to HIV-1 was in general rather poor came from CTLp and CD4 T-cell proliferation data. Long-term survivors, but not patients who had progressed to AIDS, had strong CTL responses $[9,10]$. These CTL were shown to select for viral escape mutations [11]. Interestingly, early in infection progressors appeared to have had strong CTL responses that were exhausted or deleted during progression the mechanism of which was related to enhanced T-cell turnover and perturbation of cellular immunity [12,13]. T-helper cells could be detected only in patients with a very low viral load when proliferation assays were used $[14,15]$. Interestingly, also in patients that were treated immediately during acute HIV infection with highly active antiretroviral therapy (HAART) CD4 T-helper responses apparently were preserved. This finding suggested that a proliferative T-helper response to HIV was associated with viral control and moreover that early treatment might be followed by periods of structured treatment interruption (STI) during which viral load would be contained by these now preserved HIV-specific CD4 T cells. Although the initial shortterm effect looked promising, several subsequent studies showed no sustained control by the preserved T-cell immunity during STI as the viral load quickly rebounded in almost all patients [16-19].

With the advent of new technologies, which are based on fundamentally different methods to detect antigenspecific $\mathrm{T}$ cells, it appeared that there was abundant T-cell reactivity. Strong T-cell responses were observed in asymptomatic and even still in late-stage patients when human leukocyte antigen (HLA) tetramers or interferongamma (IFN- $\gamma$ ) were used as a T-cell response marker $[20,21]$. The combination of these novel techniques allowed for detailed functional and phenotypic characterization of reactive $\mathrm{T}$ cells that appeared to correlate with disease progression markers such as CD4 T-cell numbers and viral load [22-24]. Pantaleo and coworkers [25], among others, observed a skewing in T-cell differentiation to less functional CD8 and CD4 T cells in progressors, which correlated with high viral load [26]. Several laboratories reported cross-sectional studies comparing HIV-specific T-cell properties in progressors and long-term nonprogressors (LTNP), showing a striking correlation between low viral load and preferentially polyfunctional [IFN- $\boldsymbol{\gamma}+$ interleukin (IL) $-2+$ ] central memory (CD27+ CCR7+ IL-7R+) CD4 and CD8 $\mathrm{T}$ cells [24,27-30]. Although some reservations were sometimes made regarding causality, it was widely held that these memory $\mathrm{T}$ cells that were capable of producing multiple cytokines upon in-vitro restimulation were protective T-cell responses able to control HIV-1 during chronic infection. Most of these ideas were derived from or at least fueled by a host of data from murine infectious disease models in which IL-2 producing IL-7R central memory $T$ cells were shown to protect against infection and disease by lymphocytic choriomeningitis virus (LCMV) [31]. On the basis of the correlative data from HIV natural history, in parallel, universal criteria for evaluation and monitoring of vaccine-induced T-cell immunity were agreed upon and developed among the various large vaccine-development consortia in the US and Europe.

\section{Correlation but no causality?}

The idea that a protective T-cell phenotype and function had been identified that could be used to monitor and define HIV vaccine-induced protective immunity was solely based on correlative cross-sectional data where the cause-effect relationship is unknown. In fact, several groups showed that high-level HIV viremia after STI might cause the subsequent loss of proliferative capacity and IL-2 production of HIV-specific CD4 T cells while leaving their capacity to produce IFN- $\gamma$ intact $[32,33]$. Moreover, viral load increase after STI results in a "nonprotective' T-cell phenotype that, after restarting HAART and resumed control of viral replication, reverts back to the 'protective' T-cell type. These observations indicate that viral load during chronic infection might not be, or only partially be, controlled by T-cell immunity and moreover that antigen levels seem to determine T-cell function and phenotype, and not the other way around [34,35]. Increased expression of inhibitory receptors programmed death-1 (PD-1) and cytotoxic T-lymphocyte antigen-4 (CTLA-4) on HIV-specific T cells from patients with high viral load is in good agreement with this $[36,37]$.

The hypothesis that HIV-specific memory $\mathrm{T}$ cells that have the ability to produce IL- 2 and high-level IFN- $\gamma$ are truly protective and determine subsequent AIDS-free survival was tested for the first time in a prospective cohort study in 96 seroconvertors from the Amsterdam Cohort Studies. Applying Cox proportional hazard models and Kaplan-Meier survival analyses this hypothesis was refuted for both HIV-specific CD4 [38] and CD8 T cells (Schellens et al. Presented at 'Immunological correlates of protection from HIV infection and disease' meeting; Volendam, The Netherlands; August 2006 
(submitted) [39]). In these studies, no correlation between T-cell immunity and viral set point early after infection was observed. These studies for the first time showed that abundant T-cell immunity, of the type that correlated with low viral load ('control') early in asymptomatic infection, neither prevented nor caused a delay in progression to AIDS. As it turned out progressors lose their HIV-specific T-cell immunity more rapidly during the course of infection than LTNP, this loss of immunity is most likely a consequence rather than a cause of disease progression. This confirmed data published more than a decade ago, using assays that detected memory CTL precursors, which showed that rapid progressors like LTNP had high CTL precursor frequencies early in infection which subsequently became lost during follow-up $[7,8]$. At that time, it was less clear how the early steady state with strong cellular immunity to HIV was disturbed and what could explain the deletion or exhaustion of these HIV-specific responses. Recently experimental evidence has reported that CD4 T-cell loss and disease progression are driven mainly by HIVassociated systemic immune activation that appeared to be independent from viral load [40-43]. Because of this, it appears that the pace and extent of exhaustion of the initial cellular immune response and loss of CD4 T-cells is determined by the strength of the systemic immune activation induced by HIV infection. Indeed, after the viral set point is established, the 'set point' immune activation is the best and independent predictor for progression, overriding viral load and early HIV-specific T-cell immunity as prognostic parameters [38]. This immune activation, next to HIV-induced activation of the adaptive immune system, has been shown to be induced by microbial products, including lipopolysaccharide (LPS), resulting from a breach of the gastrointestinal tract due to massive irreversible loss of memory CD4 $T$ cells during acute infection [44]. It may be envisaged that polymorphisms in genes involved in innate immune pathways determine the level of immune activation and progression.

Given all this, the lack of effect of vaccine-induced T-cell immunity on the viral load set point observed in the STEP trial, although disappointing, may not be totally unexpected. One could argue that T-cell immunity induced by viral vectors other than Ad5, or HIV genes different from HIV gene fragments than the ones included in the MRKAd5 Trivalent vaccine, might provide protection from disease progression. It may seem paradoxal that despite the fact that in acute and chronic infection T-cell immunity does exert effects on the virus, which is apparent from the strong selection for escape mutations in HLA class I restricted T-cell epitopes $[11,45]$, cellular immunity cannot truly prevent disease progression. Indeed, in rhesus macaques, AIDS vaccine failure has been shown to be associated with viral escape from CTL [5,7]. In addition, clear correlations between B57 and B27 HLA alleles, low viral load set point and long-term AIDS-free survival have been documented, in particular in so-called LTNP. Although until now progression has ultimately been seen in many LTNP that have been studied before, it may still be envisaged that some as yet undiscovered aspect of the innate or adaptive immune response in very rare 'elite controllers' provides long-term protection and may be successfully exploited for vaccine development. It may be by targeting of particularly conserved Gag epitopes [46] or through early attenuating effects of $\mathrm{B} 57$ and $\mathrm{B} 27$ restricted CTL on the incoming virus. If that type of immunity would, however, be restricted to a rare subpopulation of carriers of HLA $\mathrm{B} 57$ or B27, as has by analogy been suggested in a recent study [47] in Mamu-A*01 typed macaques, this would impose a severe and probably inhibitory limitation on the efficacy and use of a potential vaccine in most populations. Apart from this, once infection becomes established, not only the lag time required for CD4 and CD8 T-cell memory reactivation and expansion may preclude protection against infection, but HIV will also rapidly escape from CTL, diminishing protective effects of vaccine-induced immunity. Taking all this into account, it seems that we may need to return to the ambitious goal of a protective HIV vaccine that provides long-lasting sterilizing immunity mainly by way of the induction of broadly neutralizing antibodies. In the past decade, major breakthroughs have been achieved in that field and immunological and biochemical problems to be solved have been clearly identified, although at this time a vaccine candidate is not near to phase II or III trial.

\section{Reemphasise investigator-driven science}

The failure of the antibody-inducing HIV vaccines in 1994 called for a reevaluation of the global vaccine effort. At that time, a plea was made for structures and incentives to get public and private partners together in a global initiative to develop various vaccines and to prepare vaccine test sites in Africa, South America and Asia. In 1996, the International AIDS Vaccine Initiative (IAVI) was created and additional levels of global coordination were added by the Global AIDS Vaccine Initiative. European Union vaccine consortia and later the Bill and Melissa Gates Foundation Grand Challenge Program and Center for HIV/AIDS Vaccine Immunology (CHAVI). These public-private partnerships and mega consortia attracted, compared to other medical research programs, very large sums of funding and hence set the agenda for the international AIDS vaccine field. Despite 25 years of excellent and highly devoted HIV research, no vaccine is available and none will likely become available for the decade to come. After the recent failure of the STEP trial, it seems we have to go back to the drawing board and reconsider every remaining possible option for a vaccine. This approach may require that, for the near future, funding now spent via large consortia with productoriented research programs and much effort on vaccine site 
logistics is redirected to small-scale investigator-driven and ideally multidisciplinary projects. New creativity and theoretical and practical breakthroughs will have to come from the various laboratories that are committed to perform basic and translational HIV research working from many different hypotheses and angels.

Main issues, among many other promising research topics, to be addressed will be the design of immunogens able to induce broadly neutralizing antibodies and the remaining options of live-attenuated HIV vaccines and replication competent viral vectors. The negative view of HIV-1-specific humoral immunity changed with the discovery of broadly neutralizing antibodies, and at present there are options that may be quite challenging but are still viable. The observation that antibodies such as b12, 2G12, 4E10, and 2F5 could potently neutralize HIV-1 variants from different subtypes implies that certain epitopes on HIV-1 envelope are conserved between subtypes and capable of eliciting potentially protective humoral immunity [48]. Administration of the b12 antibody to monkeys, either intravenous or intravaginally, protected from infection via the intravenous or vaginal route, supporting that preexisting neutralizing antibodies can indeed provide sterilizing immunity [49-51]. Unfortunately, although progress has been made in stabilizing trimeric envelope structures the classical approaches to elicit broadly neutralizing antibodies all failed. More broadly neutralizing antibodies should be isolated from HIV-infected individuals and their epitope specificities defined, to enlarge the panel of potentially interesting epitopes that may be included in a vaccine. One obvious question to ask is why broadly neutralizing antibodies are so rare especially when most primary HIV-1 variants are sensitive to their neutralizing effect, which implies exposure of the epitopes sometime during the viral life cycle. Recent studies have shown that one of the main epitope specificities in sera from individuals with broadly neutralizing activity is the CD4 binding site. A large panel of b12-like antibodies with slightly varying epitopes may provide an interesting antibody repertoire from which HIV is unable to escape without loosing in parallel its ability to bind CD4 and infect its target cell. In the field of cellular immunity, the contribution of cellular immunity in the very rare elite non-progressors should be further studied and finally, despite discouraging results with live-attenuated SIV virus vaccines in monkeys [52] and of superinfection with HIV of HIV-infected humans [53] studies on the role of immunity in superinfection deserves attention.

\section{Acknowledgements}

Dr Hanneke Schuitemaker, AMC Amsterdam, is thanked for continuous support and frank discussions during the writing of this paper. My work is supported by the
European Union, Dutch AIDS Fund, LSBR and UMC Utrecht.

\section{References}

1. Shiver JW, Fu TM, Chen L, Casimiro DR, Davies ME, Evans RK, et al. Replication-incompetent adenoviral vaccine vector elicits effective antiimmunodeficiency-virus immunity. Nature 2002; 415:331-335.

2. Koff WC. The next steps toward a global AIDS vaccine. Science 1994; 266:1335-1337.

3. Cohen J. AIDS vaccine research. A new goal: preventing disease, not infection. Science 1993; 262:1820-1821.

4. Hirsch VM, Goldstein S, Hynes NA, Elkins WR, London WT, Zack PM, et al. Prolonged clinical latency and survival of macaques given a whole inactivated simian immunodeficiency virus vaccine. I Infect Dis 1994; 170:51-59.

5. Barouch DH, Kunstman J, Kuroda MJ, Schmitz JE, Santra S, Peyerl FW, et al. Eventual AIDS vaccine failure in a rhesus monkey by viral escape from cytotoxic T lymphocytes. Nature 2002; 415:335-339.

6. Schmitz JE, Kuroda MJ, Santra S, Saseville VG, Simon MA, et al. Control of viremia in simian immunodeficiency virus infection by CD8+ lymphocytes. Science 1999; 283:857860.

7. Koup RA, Safrit JT, Cao Y, Andrews CA, McLeod G, Borowsky $\mathrm{W}$, et al. Temporal associations of cellular immune responses with the initial control of viremia in primary human immunodeficiency virus type 1 syndrome. I Virol 1994; 68:4650-4655.

8. Klein MR, van der Burg SH, Pontesilli O, Miedema F. Cytotoxic T lymphocytes in HIV-1 infection: a killing paradox? Immunol Today 1998; 19:317-324.

9. Pantaleo G, Menzo S, Vaccarezza M, Graziosi C, Cohen OJ, Demarest JF, et al. Studies in subjects with long-term nonprogressive human immunodeficiency virus infection. $N$ Engl $/$ Med 1995; 332:209-216.

10. Ferbas J, Kaplan AH, Hausner MA, Hultin LE, Matud JL, Liu Z, et al. Virus burden in long-term survivors of human immunodeficiency virus (HIV) infection is a determinant of anti-HIV CD8+ lymphocyte activity. I Infect Dis 1995; 172:329-339.

11. Wolinsky SM, Korber BT, Neumann AU, Daniels M, Kunstman $\mathrm{KJ}$, Whetsell $\mathrm{AJ}$, et al. Adaptive evolution of human immunodeficiency virus-type 1 during the natural course of infection. Science 1996; 272:537-542.

12. Klein MR, van Baalen CA, Holwerda AM, Kerkhof Garde SR, Bende RJ, Keet IP, et al. Kinetics of Gag-specific cytotoxic T lymphocyte responses during the clinical course of HIV-1 infection: a longitudinal analysis of rapid progressors and long-term asymptomatics. J Exp Med 1995; 181:1365-1372.

13. Miedema F, Klein MR. AIDS pathogenesis: a finite immune response to blame? Science 1996; 272:505-506.

14. Rosenberg ES, Billingsley JM, Caliendo AM, Boswell SL, Sax PE, Kalams SA, Walker BD. Vigorous HIV-1-specific CD4+ T cell responses associated with control of viremia. Science 1997; 278:1447-1450.

15. Pontesilli O, Carotenuto P, Kerkhof-Garde SR, Pakker NG, de Wolf $F$, Schuitemaker $H$, Miedema F. Lymphoproliferative response to HIV type 1 p24 in long-term survivors of HIV type 1 infection is predictive of persistent AIDS-free infection. AIDS Res Hum Retroviruses 1999; 15:973-981.

16. Rosenberg ES, Altfeld M, Poon SH, Phillips MN, Wilkes BM, Eldrigde PL, et al. Immune control of HIV-1 after early treatment of acute infection. Nature 2000; 407:523-526.

17. Oxenius A, Price DA, Easterbrook PJ, O'Callaghan CA, Kelleher $A D$, Whelan $J A$, et al. Early highly active antiretroviral therapy for acute HIV-1 infection preserves immune function of CD8+ and CD4+ T lymphocytes. Proc Natl Acad Sci U S A 2000; 97:3382-3387.

18. Kaufmann DE, Lichterfeld M, Altfeld M, Addo MM, Johnston MN, Lee PK, et al. Limited durability of viral control following treated acute HIV infection. PLoS Med 2004; 1:e36.

19. Jansen CA, De Cuyper I, Steingrover R, Jurriaans S, Sankatsing SU, Prins JM, et al. Analysis of the effect of highly active antiretroviral therapy during acute HIV-1 infection on HIVspecific CD4 T cell functions. AIDS 2005; 19:1145-1154. 
20. Altman JD, Moss PA, Goulder PJ, Barouch DH, McHeyzerWilliams MG, Bell Jl, et al. Phenotypic analysis of antigenspecific T lymphocytes. Science 1996; 274:94-96.

21. Pitcher CJ, Quittner C, Peterson DM, Connors M, Koup RA, Maino VC, Picker LJ. HIV-1-specific CD4+ T cells are detectable in most individuals with active HIV-1 infection, but decline with prolonged viral suppression. Nat Med 1999; 5:518-525.

22. Appay V, Dunbar PR, Callan M, Klenerman P, Gillespie GM, Papagano $\mathrm{L}$, et al. Memory CD8+ T cells vary in differentiation phenotype in different persistent virus infections. Nat Med 2002; 8:379-385.

23. van Baarle D, Kostense S, van Oers MH, Hamann D, Miedema F. Failing immune control as a result of impaired CD8+ T-cell maturation: CD27 might provide a clue. Trends Immunol 2002; 23:586-591.

24. Pantaleo G, Koup RA. Correlates of immune protection in HIV1 infection: what we know, what we don't know, what we should know. Nat Med 2004; 10:806-810.

25. Champagne P, Ogg GS, King AS, Knabenhans C, Ellefsen $K$, Nobile $M$, et al. Skewed maturation of memory HIV-specific CD8 T lymphocytes. Nature 2001; 410:106-111.

26. Harari A, Petitpierre S, Vallelian F, Pantaleo G. Skewed representation of functionally distinct populations of virus-specific CD4 T cells in HIV-1-infected subjects with progressive disease: changes after antiretroviral therapy. Blood 2004; 103:966-972.

27. Wilson JD, Imami N, Watkins A, Gill J, Hay P, Gazzard B, et al. Loss of CD4 + T cell proliferative ability but not loss of human immunodeficiency virus type 1 specificity equates with progression to disease. I Infect Dis 2000; 182:792-798.

28. Betts MR, Nason MC, West SM, De Rosa SC, Migueles SA, Abraham J, et al. HIV nonprogressors preferentially maintain highly functional HIV-specific CD8+ T cells. Blood 2006; 107:4781-4789.

29. Jansen CA, van Baarle D, Miedema F. HIV-specific CD4+ T cells and viremia: who's in control? Trends Immunol 2006; 27:119-124.

30. Migueles SA, Laborico AC, Shupert WL, Royce C, McLaughlin $M$, Ehler $L$, et al. HIV-specific CD8+ $\mathbf{T}$ cell proliferation is coupled to perform expression and is maintained in nonprogressors. Nat Immunol 2002; 3:1061-1068.

31. Wherry EJ, Ahmed R. Memory CD8 T-cell differentiation during viral infection. / Virol 2004; 78:5535-5545.

32. MCNeil AC, Shupert WL, Iyasere CA, Hallahan CW, Mican JA, Davey RT Jr, Connors M. High-level HIV-1 viremia suppresses viral antigen-specific CD4(+) T cell proliferation. Proc Natl Acad Sci U S A 2001; 98:13878-13883.

33. Younes SA, Yassine-Diab B, Dumont AR, Boulassel MR, Grossman Z, Routy JP, Sekaly RP. HIV-1 viremia prevents the establishment of interleukin 2-producing HIV-specific memory CD4+ T cells endowed with proliferative capacity. I Exp Med 2003: 198:1909-1922.

34. Harari A, Vallelian F, Meylan PR, Pantaleo G. Functional heterogeneity of memory CD4 $\mathrm{T}$ cell responses in different conditions of antigen exposure and persistence. I Immunol 2005; 174:1037-1045.

35. Harari A, Vallelian F, Pantaleo G. Phenotypic heterogeneity of antigen-specific CD4 T cells under different conditions of antigen persistence and antigen load. Eur / Immunol 2004; 34:3525-3533.

36. Trautmann L, Janbazian L, Chomont N, Said EA, Gimmig S, Bessette $B$, et al. Upregulation of PD-1 expression on HIVspecific CD8+ T cells leads to reversible immune dysfunction. Nat Med 2006; 12:1198-1202.

37. Kaufmann DE, Kavanagh DG, Pereyra F, Zaunders IJ, Mackey EW, Miura T, et al. Upregulation of CTLA-4 by HIV-specific CD4+ T cells correlates with disease progression and defines a reversible immune dysfunction. Nat Immunol 2007; 8:12461254.
38. Jansen CA, De Cuyper I, Hooibrink B, van der Bij AK, van Baarle D, Miedema F. Prognostic value of HIV-1 Gagspecific CD4+ T-cell responses for progression to AIDS analyzed in a prospective cohort study. Blood 2006; 107:14271433.

39. Heeney JL, Plotkin SA. Immunological correlates of protection from HIV infection and disease. Nat Immunol 2006; 7:12811284.

40. Giorgi JV, Hultin LE, McKeating JA, Johnson TD, Owens B, Jacobson LP, et al. Shorter survival in advanced human immunodeficiency virus type 1 infection is more closely associated with $\mathrm{T}$ lymphocyte activation than with plasma virus burden or virus chemokine coreceptor usage. / Infect Dis 1999; 179:859-870.

41. Hazenberg MD, Otto SA, van Benthem BH, Roos MT, Coutinho RA, Lange JM, et al. Persistent immune activation in HIV-1 infection is associated with progression to AIDS. AIDS 2003; 17:1881-1888.

42. Grossman Z, Meier-Schellersheim M, Sousa AE, Victorino RM, Paul WE. CD4+ T-cell depletion in HIV infection: are we closer to understanding the cause? Nat Med 2002; 8:319323.

43. Deeks SG, Kitchen CM, Liu L, Guo H, Gascon R, Narvaez AB, et al. Immune activation set point during early HIV infection predicts subsequent CD4+ T-cell changes independent of viral load. Blood 2004; 104:942-947.

44. Brenchley JM, Price DA, Schacker TW, Asher TE, Silvestri G, Rao $\mathrm{S}$, et al. Microbial translocation is a cause of systemic immune activation in chronic HIV infection. Nat Med 2006; 12:1365-1371.

45. Haas G, Plikat U, Debre P, Lucchiari M, Katlama C, Dudoit $Y$, et al. Dynamics of viral variants in HIV-1 Nef and specific cytotoxic T lymphocytes in vivo. I Immunol 1996; 157:42124221.

46. Borghans JA, Molgaard A, de Boer RJ, Kesmir C. HLA alleles associated with slow progression to AIDS truly prefer to present HIV-1 p24. PLOS ONE 2007; 2:e920.

47. Casimiro DR, Wang F, Schleif WA, Liang X, Zhang ZQ, Tobey TW, et al. Attenuation of simian immunodeficiency virus SIVmac239 infection by prophylactic immunization with DNA and recombinant adenoviral vaccine vectors expressing Gag. J Virol 2005; 79:15547-15555.

48. Binley JM, Wrin T, Korber B, Zwick MB, Wang M, Chappey C, et al. Comprehensive cross-clade neutralization analysis of a panel of antihuman immunodeficiency virus type 1 monoclonal antibodies. / Virol 2004; 78:13232-13252.

49. Parren PW, Marx PA, Hessell AJ, Luckay A, Harouse J, ChengMayer $\mathrm{C}$, et al. Antibody protects macaques against vaginal challenge with a pathogenic R5 simian/human immunodeficiency virus at serum levels giving complete neutralization in vitro. J Virol 2001; 75:8340-8347.

50. Poignard P, Sabbe R, Picchio GR, Wang M, Gulizia RJ, Katinger $\mathrm{H}$, et al. Neutralizing antibodies have limited effects on the control of established HIV-1 infection in vivo. Immunity 1999; 10:431-438.

51. Veazey RS, Shattock RJ, Pope M, Kirijan JC, Jones J, Hu Q, et al. Prevention of virus transmission to macaque monkeys by a vaginally applied monoclonal antibody to HIV-1 gp120. Nat Med 2003; 9:343-346.

52. Wyand MS, Manson K, Montefiori DC, Lifson JD, Johnson RP, Desrosiers RC. Protection by live, attenuated simian immunodeficiency virus against heterologous challenge. J Virol 1999; 73:8356-8363.

53. Altfeld M, Allen TM, Yu XG, Johnston MN, Agrawal D, Korber BT, et al. HIV-1 superinfection despite broad CD8+ T-cell responses containing replication of the primary virus. Nature 2002; 420:434-439. 